\title{
Aristolactam-Type Alkaloids from Orophea enterocarpa and Their Cytotoxicities
}

\section{Sanchai Nayyatip ${ }^{1}$, Pak Thaichana ${ }^{2}$, Mongkol Buayairaksa ${ }^{1}$, Wirote Tuntiwechapikul ${ }^{2}$, Puttinan Meepowpan ${ }^{3}$, Narong Nuntasaen ${ }^{4}$ and Wilart Pompimon ${ }^{1}{ }_{*}$}

1 Laboratory of Natural Products, Center for Innovation in Chemistry, Faculty of Science, Lampang Rajabhat University, Lampang 52100, Thailand; E-Mails: sanchai_n@ $@$ hotmail.com (S.N.); bymongkol@gmail.com (M.B.)

2 Department of Biochemistry, Faculty of Medicine, Chiang Mai University, Chiang Mai 53000, Thailand; E-Mails: kappa_f4@hotmail.com (P.T.); wirotetunti@yahoo.com (W.T.)

3 Department of Chemistry, Center for Innovation in Chemistry, Faculty of Science, Chiang Mai University, Chiang Mai 53000, Thailand; E-Mail: pmeepowpan@gmail.com

4 The Forest Herbarium, Department of National Park, Wildlife and Plant Conservation, Ministry of Natural Resources and Environment, Bangkok 10220, Thailand;

E-Mail: narong_1960@hotmail.com

* Author to whom correspondence should be addressed; E-Mail: wilart_p@ hotmail.com;

Tel./Fax: +665-4241052.

Received: 7 March 2012; in revised form: 27 March 2012 / Accepted: 12 April 2012 /

Published: 20 April 2012

\begin{abstract}
A new aristolactam, named enterocarpam-III (10-amino-2,3,4,6-tetramethoxy phenanthrene-1-carboxylic acid lactam, 1) together with the known alkaloid stigmalactam (2), were isolated from Orophea enterocarpa. Their structures were elucidated on the basis of interpretation of their spectroscopic data. Compounds $\mathbf{1}$ and $\mathbf{2}$ exhibited significant cytotoxicities against human colon adenocarcinoma (HCT15) cell line with $\mathrm{IC}_{50}$ values of 1.68 and $1.32 \mu \mathrm{M}$, respectively.
\end{abstract}

Keywords: Orophea enterocarpa; Anonaceae; aristolactam; human colon adenocarcinoma cells; cytotoxicities 


\section{Introduction}

Orophea enterocarpa belongs to the Anonaceae family. In Thailand, this plant, called "Kloew Kang", can be found in scattered locations of the southern and eastern regions [1]. Orophea plants have been used widely as traditional medicine, for example, the root of $O$. setosa was used to cure coughs or fever [2]. Phytochemical studies on several Orophea species have been reported, resulting in the isolation of fatty acid, lignans, flavonoids and alkaloids [3-7].

A preliminary survey for biological activities of the crude methanol-dichloromethane extract of $O$. enterocarpa demonstrated that the extract exhibited cytotoxicities against lymphocylic leukemia (P-388), human carcinoma (KB), human breast adenocarcinoma (MCF7), human lung cancer (Lu-1), rat glioma (ASK), noncancerous human embryonic kidney (Hex 293) and human bladder (T24) cell lines with $\mathrm{EC}_{50}$ values of $0.20,8.56,<4.00,12.20,12.48,8.51$ and $18.69 \mu \mathrm{g} / \mathrm{mL}$, respectively. This paper deals with the isolation and structure elucidation of compounds $\mathbf{1}$ and $\mathbf{2}$ as well as their cytotoxicities against human colon adenocarcinoma (HCT15) cell line.

\section{Results and Discussion}

Successive chromatographic separation of the methanol-dichloromethane extract from the leaves and twigs of $O$. enterocarpa yielded two aristolactam-type alkaloids, a new alkaloid named enterocarpam-III (10-amino-2,3,4,6-tetramethoxyphenanthrene-1-carboxylic acid lactam, 1), together with stigmalactam (2) [8]. The structures of $\mathbf{1}$ and $\mathbf{2}$ were established by interpretation of their spectroscopic data.

Compound 1 had the molecular formula $\mathrm{C}_{19} \mathrm{H}_{17} \mathrm{NO}_{5}$, deduced from the HRESIMS mass spectrum (found $m / z 340.1184[\mathrm{M}+\mathrm{H}]^{+}$). The UV spectrum exhibited absorption at $\lambda_{\max } \mathrm{nm}(\log \varepsilon): 313$ (3.17), 359 (2.77), 386 (2.74), 550 (1.74), which corresponded to a phenanthrene chromophore [5]. The IR spectrum showed the presence of an amide group by observation of a pair of fairly strong asymmetric and symmetric $\mathrm{N}-\mathrm{H}$ stretching absorption bands at 3464 and $3167 \mathrm{~cm}^{-1}$, respectively, together with a $\mathrm{C}-\mathrm{N}$ stretching absorption band at about $1394 \mathrm{~cm}^{-1}$. The $\mathrm{C}=\mathrm{O}$ absorption band partially overlapped the $\mathrm{N}-\mathrm{H}$ bending absorption band which come into view in the range from 1699 to $1682 \mathrm{~cm}^{-1}$, making the $\mathrm{C}=\mathrm{O}$ absorption band appeared as a doublet. In addition, the aromatic phenanthrene and aralkyl ether moieties were confirmed by the IR bands at $(\mathrm{C}=\mathrm{C}) 1654,1614,1568,1533,1483,1475,1439$ and (C-O-C) 1201, 1157, correspondingly. Analysis of the NMR data (Table 1) for $\mathbf{1}$ immediately suggested a highly aromatized molecule, as the ${ }^{13} \mathrm{C}$ NMR chemical shifts suggested that 14 of the 19 carbons were aromatic. The ${ }^{1} \mathrm{H}-{ }^{1} \mathrm{H}-\mathrm{COSY}$ and $\mathrm{HMBC}$ correlations (Figure 1) identified resonances consistent with a phenanthrene moiety $\left(\delta_{\mathrm{C}} 157.6,157.1,154.2,146.0,131.8,129.7,127.8,127.7\right.$, $\left.126.1,116.1,115.9,109.5,108.5 ; \delta_{\mathrm{H}} 8.72,7.71,7.18,7.16\right)$ as well as amide carbonyl $\left(\delta_{\mathrm{C}} 167.7\right)$ and four methoxy $\left(\delta_{\mathrm{C}} 63.1,61.7,60.8,55.4 ; \delta_{\mathrm{H}}: 4.50,4.19,4.01,3.99\right) .{ }^{1} \mathrm{H}$ NMR signals pattern in the aromatic region showed the presence of two singlets at $\delta 8.72,7.16$ and two ortho coupled protons at $\delta$ 7.18 with $\delta 7.71$, respectively. It also showed four $3 \mathrm{H}$ singlets at $\delta 4.50,4.19,4.01,3.99$, indicating the presence of four $-\mathrm{OCH}_{3}$ groups. ${ }^{1} \mathrm{H}^{-}{ }^{1} \mathrm{H} \mathrm{COSY}$ and $\mathrm{NOE}$ correlations were also in support of the structure of 1 . The COSY correlations between $\delta 7.71(1 \mathrm{H}, d, J=8.8 \mathrm{~Hz}, \mathrm{H}-8)$ are interacting with $\delta 7.18(1 \mathrm{H}, d d, J=8.8$ and $2.6 \mathrm{~Hz}, \mathrm{H}-7)$ as well as long range with $\delta 8.72(1 \mathrm{H}, s, \mathrm{H}-5)$. In the 
difference NOE experiments, on irradiation of the proton at $\delta 8.72(\mathrm{H}-5)$, the signal intensities of both protons at $\delta 3.99(\mathrm{H}-6-\mathrm{OMe})$ (strong) and $\delta 4.19(\mathrm{H}-4-\mathrm{OMe})$ were enhanced significantly, indicating that two methoxy groups were located at C-4 and C-6. However, upon irradiation of $\delta 7.71(\mathrm{H}-8)$, the protons at $\delta 7.18(\mathrm{H}-7)$ and $\delta 7.16(\mathrm{H}-9)$ were enhanced. Furthermore, the NOE effect showed that the $\mathrm{H}-7$ ( $\delta$ 7.18) signal was enhanced upon irradiation of 6-OMe $(\delta 3.99)$, suggesting the placement of the aromatic methoxy group at C-6. The key HMBC correlations from aromatic proton $\mathrm{H}-5(\delta 7.18)$ to $\mathrm{C}-4 \mathrm{a}(\delta$ 127.7), C-4b ( $\delta$ 115.9), C-1 ( $\delta$ 109.5), indicated the obviously chemical shift of the quaternary carbon, especially position 1 unambiguously [4-6]. Additionally, the HMBC correlations between the aromatic protons $\mathrm{H}-7$ ( $\delta$ 7.18), $\mathrm{H}-8(\delta$ 7.71) and $\mathrm{H}-9$ (7.16) to (C-4a, C-6, C-8a) and (C-4a, C-6, C-7, C-8a, C-9) and (C-4a, C-4b, C-8, C-8a), respectively, established the phenanthrene of aristolactam-type alkaloid skeleton. In addition, the EIMS mass spectrum (found $m / z 339,\left[\mathrm{M}^{+}\right]$) showed typical aristolactam structure. The key fragmentation ions in the mass spectrum at $m / z, 324,198,171$ and 170 were useful to obtain the structure of 1 (Figure 2). The principal ions were associated with loss of methyl and carbonyl derived from initial cleavages around the methoxy functions [9]. The presence of the methyl groups were confirmed by the fragment ions at $m / z$ 324. In addition, the fragment ions at $m / z 198\left(\mathrm{M}^{+}\right.$-Me-Me-4CO) and $m / z 171$ ( $\mathrm{M}^{+}$-Me-Me-4CO-HCN) indicated the presence of the amide group. Moreover, methylation of a known alkaloid $\mathbf{2}$ was performed to confirm that compound $\mathbf{1}$ is its methyl derivative. On the basis of the spectral data, the structure of compound $\mathbf{1}$ was recognized as 10-amino-2,3,4,6-tetramethoxyphenanthrene-1-carboxylic acid lactam (enterocarpam-III). This compound is being reported for the first time from a natural plant source.

Table 1. NMR chemical shifts $(\delta)$ of compounds 1 and $2\left({ }^{1} \mathrm{H}: 400 \mathrm{MHz}\right.$ and $\left.{ }^{13} \mathrm{C}: 100 \mathrm{MHz}\right)$.

\begin{tabular}{ccccc}
\hline \multirow{2}{*}{ Position } & \multicolumn{2}{c}{$\mathbf{1}\left(\mathbf{C D C l}_{\mathbf{3}}\right)$} & \multicolumn{2}{c}{$\mathbf{2}$ (acetone- $\left.\boldsymbol{D}_{\mathbf{6}}\right)$} \\
\cline { 2 - 5 } & $\boldsymbol{\delta}_{\mathbf{H}} \mathbf{m}(\boldsymbol{J}=\mathbf{H z})$ & $\boldsymbol{\delta}_{\mathbf{C}}(\mathbf{D E P T})$ & $\boldsymbol{\delta}_{\mathbf{H}} \mathbf{m}(\boldsymbol{J}=\mathbf{H z})$ & $\boldsymbol{\delta}_{\mathbf{C}}(\mathbf{D E P T})$ \\
\hline 1 & - & $109.5(\mathrm{C})$ & - & $109.8(\mathrm{C})$ \\
2 & - & $154.2(\mathrm{C})$ & - & $149.2(\mathrm{C})$ \\
3 & - & $146.0(\mathrm{C})$ & - & $144.0(\mathrm{C})$ \\
4 & - & $157.1(\mathrm{C})$ & & $158.3(\mathrm{C})$ \\
$4 \mathrm{a}$ & - & $127.7(\mathrm{C})$ & - & $129.1(\mathrm{C})$ \\
$4 \mathrm{~b}$ & - & $115.9(\mathrm{C})$ & - & $123.5(\mathrm{C})$ \\
5 & $8.72 s$ & $108.5(\mathrm{CH})$ & $8.75 d(2.7)$ & $109.2(\mathrm{CH})$ \\
6 & - & $157.6(\mathrm{C})$ & - & $150.3(\mathrm{C})$ \\
7 & $7.18 d d(8.8,2.6)$ & $116.1(\mathrm{CH})$ & $7.20 d d(8.8,2.7)$ & $116.8(\mathrm{CH})$ \\
8 & $7.71 d(8.8)$ & $129.7(\mathrm{CH})$ & $7.80 d(8.8)$ & $130.5(\mathrm{CH})$ \\
$8 \mathrm{a}$ & - & $127.8(\mathrm{C})$ & - & $129.1(\mathrm{C})$ \\
9 & $7.16 s$ & $106.4(\mathrm{CH})$ & $7.15 s$ & $104.8(\mathrm{CH})$ \\
10 & - & $131.8(\mathrm{C})$ & - & $133.9(\mathrm{C})$ \\
$10 \mathrm{a}$ & - & $126.1(\mathrm{C})$ & - & $128.5(\mathrm{C})$ \\
11 & $9.30 b r s$ & - & - & - \\
12 & - & $167.7(\mathrm{C})$ & - & $167.3(\mathrm{C})$ \\
$2-\mathrm{OMe}$ & $4.50 s$ & $63.1\left(\mathrm{CH}_{3}\right)$ & $4.55 s$ & $63.0\left(\mathrm{CH}_{3}\right)$ \\
$3-\mathrm{OMe}$ & $4.01 s$ & $61.7\left(\mathrm{CH}_{3}\right)$ & $4.00 s$ & $55.7\left(\mathrm{CH}_{3}\right)$ \\
$4-\mathrm{OMe}$ & 4.19 & $60.8\left(\mathrm{CH}_{3}\right)$ & $4.20 s$ & $60.2\left(\mathrm{CH}_{3}\right)$ \\
$6-\mathrm{OMe}$ & $3.99 s$ & $55.4\left(\mathrm{CH}_{3}\right)$ & - & - \\
$6-\mathrm{OH}$ & - & - & $8.35 s$ & - \\
\hline
\end{tabular}


Figure 1. Structures of compounds 1 and 2 together with NOE experiment, significant correlations in the COSY, HMBC spectra.
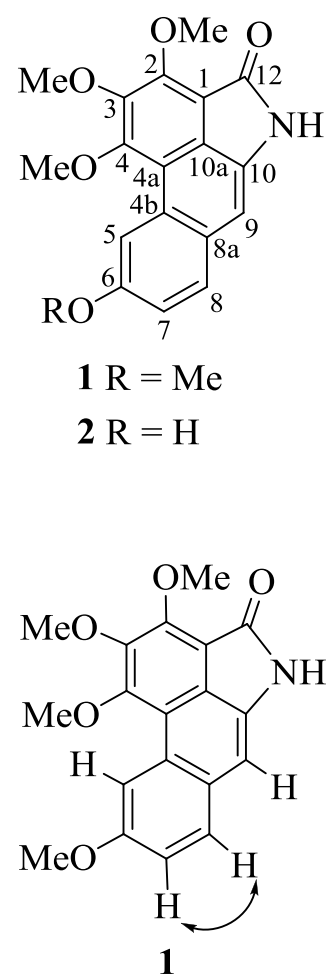

${ }^{1} \mathrm{H}-{ }^{1} \mathrm{H}-\mathrm{COSY}$ correlation

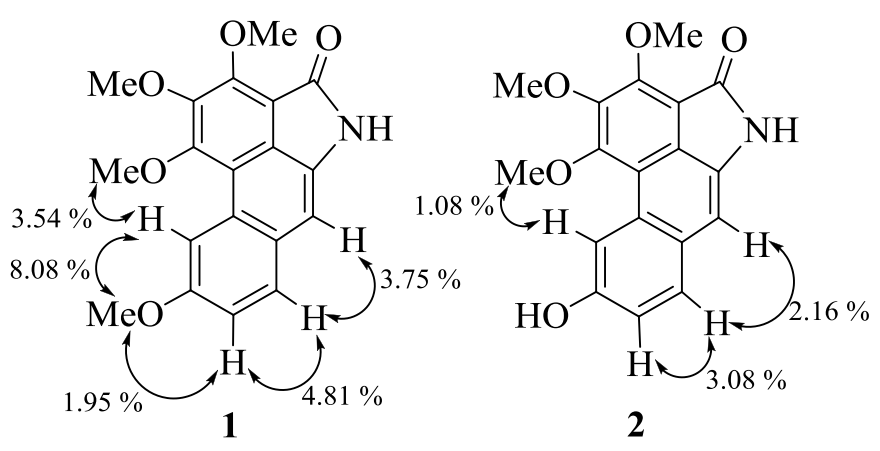

significant NOE experiments
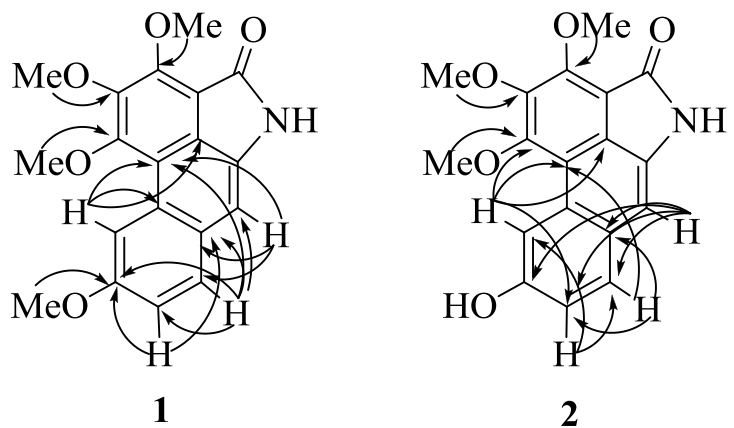

long-range $\mathrm{HMBC}$ correlations

Figure 2. The EIMS mass fragmentations of compound 1.

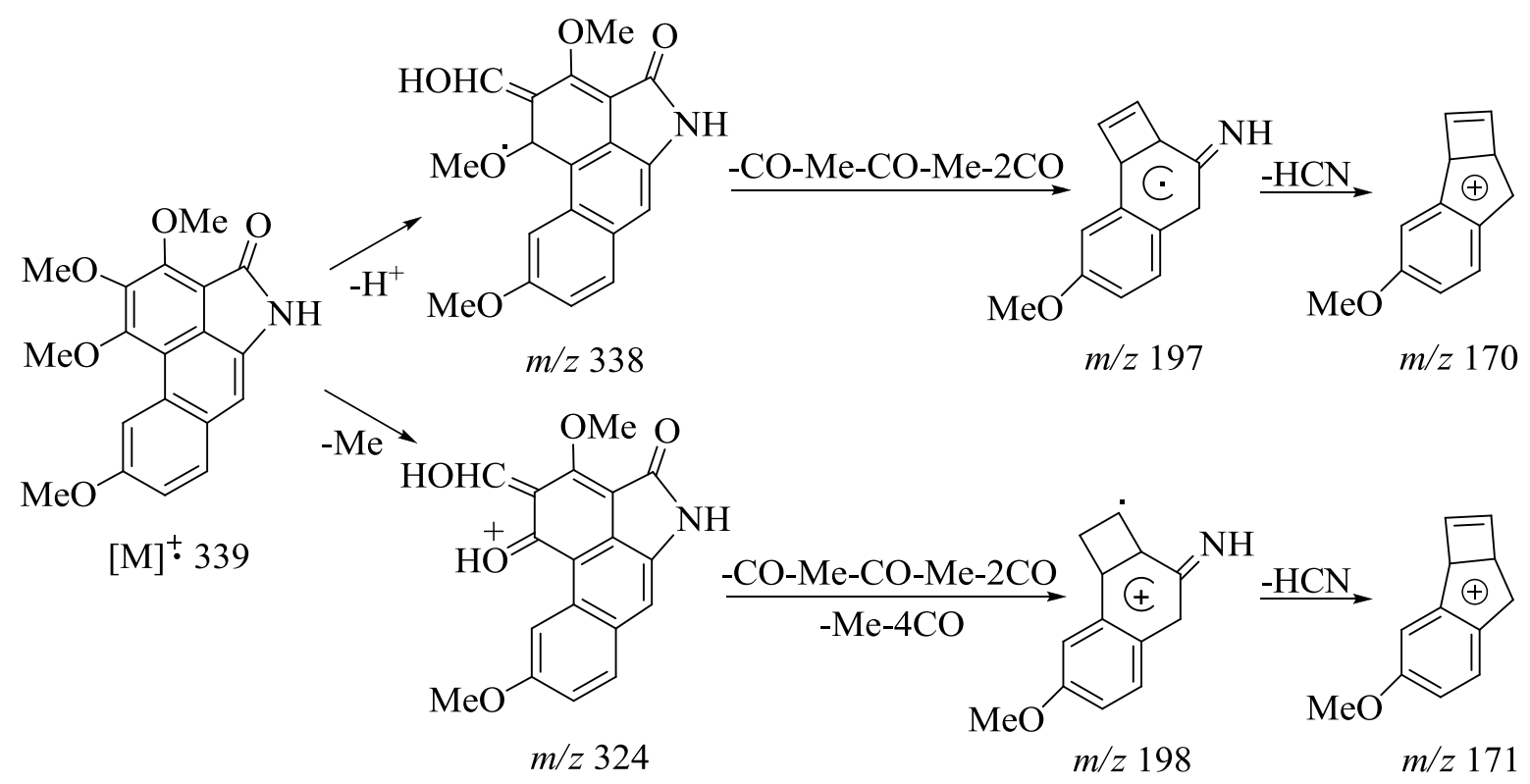

We investigated whether these compounds could have cytotoxic activities in human colon adenocarcinoma cell line HCT15 using the Sulforhodamine B (SRB) colorimetric assay. The 50\% growth inhibitory concentrations $\left(\mathrm{IC}_{50}\right)$ were determined from the dose-response relationships between the compound concentrations and the percentage of growth inhibitions (Figure 3). The $\mathrm{IC}_{50}$ values measured for compounds 1 and 2 were $1.68 \pm 0.07$ and $1.32 \pm 0.03 \mu \mathrm{M}$, respectively. These data 
represent the mean value \pm standard deviation of three independent experiments performed in triplicate. We also used the same system to test some established cancer therapeutic agents such as carboplatin, gemcitabine, and vinorelbine; the $\mathrm{IC}_{50}$ values measured for these compounds were $37.2 \pm 4.4$, $0.74 \pm 0.07$ and $0.018 \pm 0.002 \mu \mathrm{M}$, respectively.

Figure 3. $\mathrm{IC}_{50}$ evaluations on HCT15 cells. Dose-response curves between the compound concentrations and percentages of control cell growth were plotted. $\mathrm{IC}_{50}$ values were derived using the software Curve Expert 1.4. The data represent the mean value \pm standard deviation of three independent experiments performed in triplicate. (A) The $\mathrm{IC}_{50}$ values measured for compounds 1 and 2 were $1.68 \pm 0.07$ and $1.32 \pm 0.03 \mu \mathrm{M}$, respectively. (B) The $\mathrm{IC}_{50}$ value of carboplatin was $37.2 \pm 4.4 \mu \mathrm{M}$. (C) The $\mathrm{IC}_{50}$ value of gemcitabine was $0.74 \pm 0.07 \mu \mathrm{M}$. (D) $\mathrm{The} \mathrm{IC}_{50}$ value of vinorelbine was $0.018 \pm 0.002 \mu \mathrm{M}$.
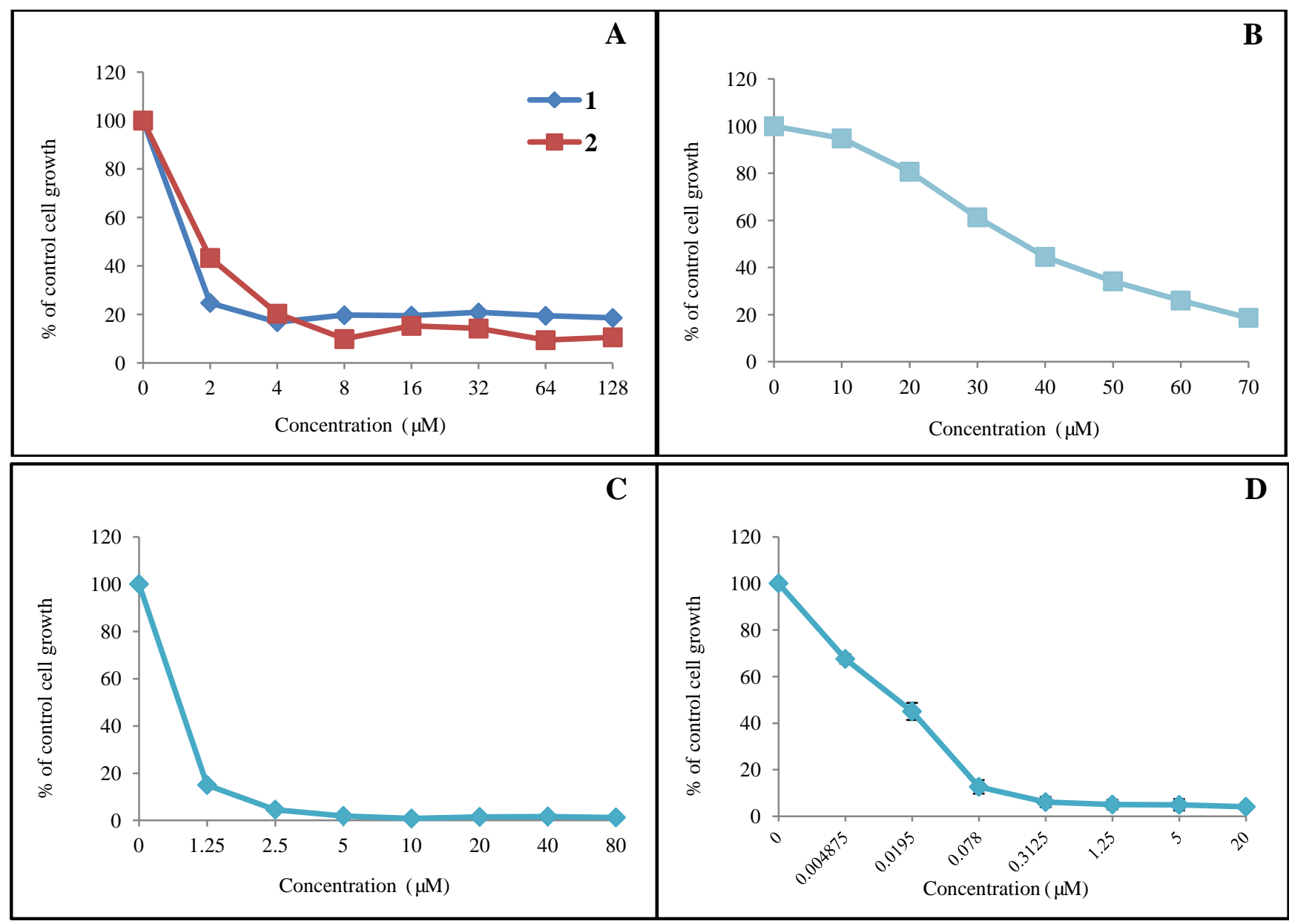

\section{Experimental Section}

\subsection{General}

Melting points were measured on a Büchi 322 micro melting point apparatus and were uncorrected. Infrared spectra were recorded as $\mathrm{KBr}$ pellets using a Shimadzu 8900 FTIR spectrophotometer. Ultraviolet absorption spectra were measured in methanol solution on Shimadzu 1601 spectrophotometer. High resolution mass spectra (electrospray ionization mode, ESI-MS) were 
measured on a micromass Q-TOF-2 ${ }^{\mathrm{TM}}$ (Waters) spectrometer. Low resolution mass spectra were recorded on a Thermo Finnigan Polaris Q mass spectrometer at $70 \mathrm{eV}$ (probe) for EIMS carried out with a Bruker Esquire. The ${ }^{1} \mathrm{H}$ and ${ }^{13} \mathrm{C}-\mathrm{NMR}$ (1D and 2D) spectra were recorded using a Bruker DPX 400 spectrometer and were recorded as $\delta$ value in ppm down field from TMS. Silica gel $60 \mathrm{H}$ (E. Merck.70-230 mesh ASTM, cat. No.7734.) was used for column chromatography (CC). Solvents for extraction, chromatography and recrystallization were distilled before uses. Fractions obtained from CC were mornitored by TLC (pre-coated silica gel $60 \mathrm{~F}_{254}, 20 \times 20 \mathrm{~cm}$, MERCK).

\subsection{Plant Material}

The leaves and twigs of $O$. enterocarpa were collected from Prajeanburi, Province in Thailand, in March 2009 and were identified by N. Nuntasaen. A voucher specimen (BKF no.151499) was deposited at the Forest Herbarium, Department of National Park, Wildlife and Plant Conservation, Ministry of Natural Resources and Environment, Bangkok, Thailand.

\subsection{Isolation and Extraction}

Air-dried leaves and twigs of $O$. enterocarpa $(2.7 \mathrm{~kg})$ were ground and then defatted successively with hexane $(3 \times 19 \mathrm{~L})$ and extracted subsequently with methanol-dichloromethane $(3: 1)(11 \times 52 \mathrm{~L}$. $)$ Removal of the solvent from each extract under reduced pressure gave the crude hexane $(15.83 \mathrm{~g})$ and methanol-dichloromethane (211.18 g) extracts, respectively. The methanol-dichloromethane extract (211.2 g) was further separated by flash CC over silica gel (Merck 7737, Mesh 70-230, $700 \mathrm{~g}$ ). Gradient elution was conducted initially with n-hexane, gradually enriched with ethyl acetate, followed by increasing amount of methanol in ethyl acetate and finally with methanol to afford eleven fractions, $\mathrm{F}_{1}-\mathrm{F}_{11}$. Fraction $\mathrm{F}_{4}(16.6 \mathrm{~g})$ was rechromatograpged by $\mathrm{CC}$ over silica gel eluted with gradient system between hexane, ethyl acetate and methanol to give five subfractions, $A_{1}-A_{5}$. The pale yellow precipitate in subfraction $\mathrm{A}_{4}$ was recrystallized from ethanol to obtain compound $\mathbf{1}(0.28 \mathrm{~g})$. Fraction $\mathrm{F}_{4}$ (3.8 g) further separated by $\mathrm{CC}$ over silica gel using gradient elution of hexane, ethyl acetate and methanol to obtain four subfractions, $\mathrm{B}_{1}-\mathrm{B}_{4}$. The subfraction $\mathrm{B}_{3}(0.38 \mathrm{~g})$ then underwent repeated purified with the same procedure to afford four subfractions, $\mathrm{C}_{1}-\mathrm{C}_{4}$. The yellow precipitate in subfraction $\mathrm{C}_{2}$ was recrystallized from ethanol to give compound $2(0.07 \mathrm{~g})$.

\subsection{Enterocarpam-III (1)}

Yellow crystals, m.p. $183-184{ }^{\circ} \mathrm{C}$; UV $\lambda_{\max }(\mathrm{MeOH})(\log \varepsilon): 313(3.17), 359$ (2.77), 386 (2.74) and 550 (1.74) nm; IR (KBr) v (cm $\left.{ }^{-1}\right): 3464,3167,1699,1682,1654,1614,1568,1533,1483,1475,1439$, 1201, 1157. ${ }^{1} \mathrm{H}$ NMR $\left(\mathrm{CDCl}_{3}, 400 \mathrm{MHz}\right)$ and ${ }^{13} \mathrm{C} \mathrm{NMR}\left(\mathrm{CDCl}_{3}, 100 \mathrm{MHz}\right)$ : Table 1. HRESIMS $m / z 340.1184[\mathrm{M}+\mathrm{H}]^{+}$(calcd for $\mathrm{C}_{19} \mathrm{H}_{17} \mathrm{NO}_{5}+\mathrm{H}, 340.1185$ ). EIMS $\mathrm{m} / z$ (rel.int.\%): 339 (100), 324 (28), 310 (17), 296 (15), 281 (19), 266 (24), 210 (18), 198 (12), 171 (10) and 170 (9). COSY correlations H/H: 7/8; 8/7. HMBC correlations: see Figure 1. 


\subsection{Stigmalactam (2)}

Yellow crystals, m.p. 275-276.5 ${ }^{\circ} \mathrm{C}$ [8], UV $\lambda_{\max }(\mathrm{MeOH})(\log \varepsilon): 394(2.34), 298$ (2.62) and 242 (2.90) nm; IR (KBr) $\vee\left(\mathrm{cm}^{-1}\right): 3550,3431,1679,1614,1599,1419,1332,1236,1195,1061$. ${ }^{1} \mathrm{H}$ NMR (Acetone- $D_{6}, 400 \mathrm{MHz}$ ) and ${ }^{13} \mathrm{C}$ NMR (Acetone- $D_{6}, 100 \mathrm{MHz}$ ): Table 1. HRESIMS $m / z 326.1029[\mathrm{M}+\mathrm{H}]^{+}$(calcd for $\left.\mathrm{C}_{18} \mathrm{H}_{14} \mathrm{NO}_{5}+\mathrm{H}, 326.1028\right)$. EIMS $m / z$ (rel.int.\%): 325 (100), 310 (20), 307 (22), 292 (19), 282 (24), 279 (14), 267 (16), 264 (25), 239 (13). COSY correlations H/H: 5/7; 7/5, 7/8; 8/7. HMBC correlations: see Figure 1.

Methylation of Stigmalactam: To a solution of stigmalactam $(3.9 \mathrm{mg}, 0.012 \mathrm{mmol})$ in anhydrous acetone $(5 \mathrm{~mL})$ was added excess MeI and the mixture was stirred at room temperature for $4 \mathrm{~h}$. The crude reaction mixture was filtered and concentrated in vacuo. The crude product was purified by preparative thin layer chromatography (EtOAc-hexane $=4: 6$ as developing solvent) gave enterocarpam-III (1) (3.7 mg, 91\% yield).

\subsection{Cytotoxicities}

\subsubsection{Cell Lines and Culture Conditions}

The human colon adenocarcinoma cell line HCT15 was obtained from American Type Culture Collection (Rockville, MD). The HCT15 cells were grown in Roswell Park Memorial Institute medium 1640 (RPMI 1640) with 10\% fetal bovine serum (FBS) and 1\% antibiotics (50 units/mL penicillin, $50 \mu \mathrm{g} / \mathrm{mL}$ streptomycin). The HCT15 cells were grown as monolayer at $37{ }^{\circ} \mathrm{C}$ in a humidified atmosphere of $5 \% \mathrm{CO}_{2}$ and $95 \%$ air.

\subsubsection{Sulforhodamine B (SRB) Colorimetric Assay}

Cell survival was determined by using the colorimetric Sulforhodamine B assay. The assay relies on the ability of Sulforhodamine B to bind to protein components of cells that have been fixed to tissue-culture plates by trichloroacetic acid (TCA). Sulforhodamine B is bright-pink aminoxanthane dye with two sulfonic groups that bind to basic amino-acid residues under mild acidic conditions, and dissociate under basic conditions. As the binding of Sulforhodamine B is stoichimetric, the amount of dye extracted from stained cells is directly proportional to the cell mass.

Sulforhodamine B Assay Protocol: The growth inhibition of HCT15 cells was determined using the Sulforhodamine B (SRB) assay according to a published protocol. Briefly, after adjusting the cell concentration with Roswell Park Memorial Institute medium 1640 (RPMI 1640) supplemented with $10 \%$ fetal bovine serum (FBS) and $1 \%$ antibiotics (50 units $/ \mathrm{mL}$ penicillin, $50 \mu \mathrm{g} / \mathrm{mL}$ streptomycin) to obtain seeding density at $1 \times 10^{4}$ cells/well, the cell suspensions were seeded in 96-well tissue-culture plates, which were pre-added with various concentrations of the test sample. The cell suspensions were occasionally mixed during plating to ensure an even distribution of the cells. The cells were allowed to attach for $2-3 \mathrm{~h}$ at $37{ }^{\circ} \mathrm{C}$ in a humidified incubator with $5 \% \mathrm{CO}_{2}$. The first plate, as a no-growth control (day 0), was proceeded to fix the cell monolayer, whereas the remaining plates were incubated at $37{ }^{\circ} \mathrm{C}$ in a humidified incubator with $5 \% \mathrm{CO}_{2}$ for $72 \mathrm{~h}$. At the end of each treatment, the cells were fixed by gentle addition of $100 \mu \mathrm{L}$ of cold $10 \%(\mathrm{wt} / \mathrm{v})$ trichloroacetic acid (TCA) to each well, 
followed by incubation at $4{ }^{\circ} \mathrm{C}$ for $1 \mathrm{~h}$. Plates were washed four times with deionized water and removed excess water using paper towels. The plates were then left to air dry at room temperature $\left(20-25^{\circ} \mathrm{C}\right)$. Cells were stained with $100 \mu \mathrm{L}$ of SRB solution $(0.057 \% \mathrm{SRB} w \mathrm{wt} / \mathrm{v}$ in $1 \%$ acetic acid), which was added to each well for $30 \mathrm{~min}$ at room temperature. The plates were then quickly rinsed four times with $1 \%(\mathrm{v} / \mathrm{v})$ acetic acid to remove unbound dye and allowed to dry at room temperature. Next, bound dye was solubilized with $10 \mathrm{mM}$ Tris base solution ( $\mathrm{pH}$ 10.5). The optical density (OD) was read at $510 \mathrm{~nm}$ using a fluorescence plate reader (Biotech K40). The absorbance values of treated samples were calculated as the percentage of cell-growth inhibition using the formula below:

$$
\begin{gathered}
\% \text { of control cell growth }=\frac{\text { mean OD sample }- \text { mean OD day } 0 \times 100}{\text { mean OD neg. control }- \text { mean OD day } 0} \\
\% \text { growth inhibition }=100-\% \text { of control cell growth }
\end{gathered}
$$

For $\mathrm{IC}_{50}$ determination, a dose-response curve between the compound concentration and percent of control cell growth was plotted. $\mathrm{IC}_{50}$ values were derived using the software Curve Expert 1.4.

\section{Conclusions}

The present study demonstrated, for the first time, that enterocarpam-III and stigmalactam isolated from the leaves and twigs of $O$. enterocarpa, possesses in cytotoxicities. As seen from the $\mathrm{IC}_{50}$ values, our compounds were within the range of these established cancer therapeutic agents. Therefore, these compounds could potentially be useful as chemotherapeutic agents, but much further investigation is still needed.

\section{Acknowledgments}

We thank to Aphichat Suksamran (Ramkhamhaeng University) for providing us their NOE data. Financial assistance from the Center for Innovation in Chemistry (PERCH-CIC), Commission on Higher Education, Ministry of Education is gratefully acknowledged.

\section{References}

1. Smitinand, T. Thai Plant Name, Revised ed.; Prachachon: Bangkok, Thailand, 2001; p. 386.

2. Perry, L.M.; Metzger, J. Medicinal Plants of East and Southeast Asia: Attributed Properties and Uses; MIT Press: Cambridge, MA, USA, 1980; p. 620.

3. Cavin, A.; Potterat, O.; Wolfender J.L.; Hostettmann, K.; Dyatmyko, W. Use of on-flow $\mathrm{LC} /{ }^{1} \mathrm{H}$ NMR for the study of an antioxidant fraction from Orophea enneandra and isolation of a polyacetylene, lignans and a tocopherol derivative. J. Nat. Prod. 1998, 61, 1497-1501.

4. Lajis, N.H.; Khan, M.N.; Kiew, R.; Bremner, J.B. The Flavonoids of Orophea polycarpa A. DC. (Anonaceae). Pertanika J. Sci. Technol. 1993, 1, 195-198.

5. Mahmood, K.; Chan, K.C.; Park, M.H.; Han, Y.N.; Han, B.N. Aritolactams of Orophea enterocarpa. Phytochemistry 1985, 25, 965-967.

6. Sinz, A.; Matusch, R.; Witte, L. Alkaliods from Orophea hexandra. Biochem. Syst. Ecol. 1999, 27, 111-112. 
7. Teruna, H.Y.; Waterman, P.G. Alkaloids from the bark of Orophea hexandra (Annonaceae). Biochem. Syst. Ecol. 2007, 35, 454-455.

8. Chia, Y.C.; Chang, F.F.; Teng, C.M.; Wu, Y.C. Aristolactams and dioxoaporphines from Fissisigma balansae and Fissistigma oldhamii. Phytochemistry 2000, 63, 1160-1163.

9. Atta-ur-Rahman, Ed. Studies in Natural Products Chemistry: Bioactive Natural Products (Part L); Elsevier: Amsterdam, The Netherlands, 2005; Volume 32, pp. 966-967.

(C) 2012 by the authors; licensee MDPI, Basel, Switzerland. This article is an open access article distributed under the terms and conditions of the Creative Commons Attribution license (http://creativecommons.org/licenses/by/3.0/). 